\title{
Progressive Urbanism in Small Towns: The Contingencies of Governing From the Left
}

Urban Affairs Review 2023, Vol. 59(I) 43-72 (C) The Author(s) 2021

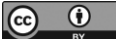

Article reuse guidelines: sagepub.com/journals-permissions DOI: $|0.1| 77 /|07808742| 1055834$ journals.sagepub.com/home/uar

(S)SAGE

\author{
Ross Beveridge' \\ and Matthias Naumann ${ }^{2}$
}

\begin{abstract}
The progressive potential of urban politics is the subject of growing interest. However, debates have been largely focused on large cities with strong progressive constituencies of activists and Left-voting residents. We know little about the opportunities and challenges for progressive politics in smaller urban areas. This article addresses these shortcomings through a discussion of "progressive urbanism" in relation to small towns. In doing so, it makes three main contributions. First, it provides a definition of progressive urbanism as political projects of social justice, citizenship and democracy exploring the contingent potential of "localism," "urban movements" and "municipal government." Second, the article provides empirical insights on small towns in the German state of Brandenburg governed by mayors of the Left Party. Third, the article outlines challenges and opportunities of progressive urbanism in small towns, providing points of reflection for future research.
\end{abstract}

\section{Keywords}

urban politics, urban governance, small towns, political geography, progressive politics

\footnotetext{
'School of Social and Political Sciences, University of Glasgow, Glasgow, UK

${ }^{2}$ Department of Geography and Regional Studies, University of Klagenfurt, Klagenfurt, Austria

Corresponding Author:

Ross Beveridge, School of Social and Political Sciences, University of Glasgow, 25 Bute Gardens, Glasgow GI2 8RT, UK.

Email: Ross.Beveridge@glasgow.ac.uk
} 


\section{Introduction}

Can city governments be a force for progressive change? What resources do they draw upon to confront the inevitable obstacles they encounter, and how do these shape the scope and ambition of policy makers? Despite continued urban austerity (Peck 2012; Theodore 2020), urban entrepreneurialism (Beswick and Penny 2018; Fuller 2018), and the deep failures of liberal urban policy (Imbroscio 2019), the possibilities of urban government have become the focus of renewed interest in urban studies (Tonkiss 2020; Joy and Vogel 2021). Notions such as "Progressive City" (Clavel 2010), "Radical Cities" (Baiocchi and Gies 2019), "Progressive Localism" (Featherstone et al. 2012), and the "New Municipalism" (Thompson 2021), capture diverse political projects around the world aimed at democratizing local government, contesting inequalities, and promoting citizenship. Writing in this journal, Joy and Vogel (2021) proposed an agenda for progressive urban policy makers to move beyond the neoliberal paradigm and challenged urban scholars to catch up with the "burgeoning literature and practical possibilities in urban policy making" (27). This article takes up their challenge and shifts the focus to the contingencies of governing from the Left: the situated concerns, resources, and strategies apparent as progressive politicians envisage and encounter constraints and opportunities.

This article aims to throw light on the scope of progressive urban government, engaging with generic and specific factors that shape gains, compromises, and retreats. It is assumed that by definition "progressive" projects always entail some kind of accommodation with the existing political context, a certain gradualism - unlike, an overtly radical project, for instance. The political potential and limits of progressive projects lie in the areas where accommodation with the status quo is, or is not, made. This paper probes these areas, accepting that the scope of progressive urbanism projects will always be context-specific; recognizing that the reasons for challenging or compromising and the lack of political capacity or will is contingent upon situated struggles. Nonetheless, through exploring these issues, we ask important questions about the political potential of the "urban" as a space within which new ways of thinking and new forms of political action emerge (Lefebvre 2003; Boudreau 2017).

The academic and activist debate on progressive urban politics tends to be, understandably, drawn to the more dramatic cases of the capital cities and larger metropoles, such as Barcelona and Berlin, with their strong urban social movements and wide range of progressive projects. Smaller cities are sometimes discussed, but more so as political "models" of community wealth building in postindustrial contexts, such as in Preston (UK) and Cleveland (USA), and of co-operativism as a strategy for achieving economic 
and racial justice, such as in Jackson, Mississippi (USA) (Thompson 2021). Crucially, and in line with our objectives here, urban scholars have moved beyond declaratory or definitional work and have begun to reflect on the contingencies and achievements of these emancipatory political projects (Blanco, Salazar, and Bianchi 2020; Janoschka and Mota 2020; Davies 2021). Progressive urban scholars and activists alike are understandably keen to support promising ideas, policies, and projects, however, productive engagement must also be characterized by expansive and critical reflection. Hence, it is necessary to look beyond the well-known and inspiring cases and gain a sense of the potential of progressive projects developing outside of the limelight (Featherstone, Littler, and Davison 2020).

Against this background, this article makes three main contributions. First, we develop a definition of progressive urbanism along three constituent dimensions that are seen to shape its political scope and potential: localism, urban movements, and municipal government. Second, we shift the analytical focus to small towns, which we define as a place with a population of up to around 50,000 residents. After a discussion that locates small towns in the debate on progressive urbanism, the article provides empirical insights on political projects of the Left Party (DIE LINKE) in small towns in the German state of Brandenburg, delineating key strategies and policies as well as highlighting constraints and opportunities seen by politicians at this scale. Third, we propose a means of considering the contingencies of progressive urbanism in small towns and consider the implications for the wider debate. Our general arguments and examples are drawn from, and directed mainly to, contexts in the Global North but are not exclusive to them. Progressive urbanism is apparent in diverse global contexts (Douglass, Garbaye, and Ho 2019), and the ideas present here may be relevant to some of them.

Small towns rarely make an appearance in discussions on urban politics, let alone progressive variants of it. Indeed, there is a sense that small towns are a problem for progressive urban politics, at least in the Global North, where they have become associated with economic decline and the reactionary populist right, part of the so-called "revenge of the places that don't matter" (Rodríguez-Pose 2017). However, although there are examples of progressive politics in smaller urban places, there is a lack of research on the topic that reflects the wider neglect of small towns in urban studies, despite their continued prevalence as an urban form (Bell and Jayne 2009). As a result, we know comparatively little about the constraints on, and opportunities for, progressive politics at this scale, despite an abundance of work on the challenges of governing larger cities (e.g., see the vast urban regime literature).

In shifting the analytical focus to small towns, it is important to avoid looking at them through the lens of the larger city-to not depart from a 
"center" of knowledge production, an essentialized or theorized superior (i.e., the metropole), and seek out difference and diversity in progressive politics. In this very specific context, progressive urbanism in the small-town context of Brandenburg departs from existing, sometimes failed projects and pivots away from formal politics and established parties, as well as more conventional societal organizations such as religious associations and sports clubs.

The paper proceeds as follows: Section 2 defines progressive urbanism drawing on debates from urban politics; Section 3 discusses the marginal presence of small towns in debates on progressive urbanism; section 4 details the findings from our interviews with small-town mayors from Brandenburg; Section 5 provides reflections on the contingencies of progressive urbanism in small towns; and Section 6 offers conclusions.

\section{What is Progressive Urbanism?}

Cities appear to offer rich potential for progressive politics, as evidenced by the potent historical urban imaginary centered on the Paris Commune, as well the iconic cases of leftists in urban government, such as "Red Vienna" and "Red Bologna." More recently, we have seen discussions on "Progressive Cities" in the 1970s and 1980s United States-Berkeley, Burlington, Hartford, and Santa Monica, as well as larger cities such as Boston, Cleveland, and Chicago (Clavel 1986; 2010); the "New Urban Left" in 1980s Britain, including London, Sheffield, and Walsall (Boddy and Fudge 1984); the "Radical Cities" of Latin America between the 1980s and 2000s like Porto Alegre (Brazil), Montevideo (Uruguay), and Rosario (Argentina) (Baiocchi and Gies 2019); and the "new municipalism" that emanated from urban Southern Europe in the 2010s, most notably Barcelona, and has also become associated with Preston (UK) and Jackson, Mississippi (USA) (Russell 2019; Thompson 2021).

Although diverse, the above projects can be seen as examples of what we propose to define as "progressive urbanism:" political projects aimed at increasing social justice, citizenship, and democracy in relation to municipal or local government and the lived spaces, places, and processes of urban life. The term urbanism can be seen as encompassing an entire way of life bound up with towns and cities, as Magnusson (2015) argues. Hence, in referring to urbanism we draw attention to wider political struggles over social-material processes of urban areas (Beveridge and Koch 2019).

"Progressive" is a disputed political term and terrain, with liberal and radical interpretations (Joy and Vogel 2021). The term "progressive" denotes those political forces, which despite their divergences, share a general commitment to social justice and positive freedoms (see della Porta 
2020, 8). More radical strands may co-exist alongside more reformist, social movements aiming for transformative change, next to municipal governments pushing for incremental gains. Hence, the term is used in an encompassing rather than exclusionary way, and does not delineate between often competing projects, but brings them into conversation with each other.

As a form of leftist politics, "progressive" can be understood as meaning a general moving forward, an attempted shift. It is suggestive of a productive engagement with existing political, economic, and social structures, even if the aim is their transformation. This, in turn, suggests inherent tensions within, and ongoing limits on, the extent or scope of political ambition and potential as institutional politics and party politics comes into play. It can, thus, be speculated that even if a progressive political project incorporates more radical elements, as political coalitions often do, it remains distinct from an overtly radical political project, which might be understood as seeking a more definitive switch, a perhaps swifter or more thorough overhaul of existing structures as part of their transformation. Of course, there may be tensions within progressive projects between those who envisage a longer and more far-reaching process of change and those whose political ambitions are more contained. Such divisions are, of course, common to all political projects, including progressive political parties, which are always made up of coalitions of interests.

Recent work conducted on progressive urban politics tends to foreground policy and other instruments of governmental intervention (Tonkiss 2020; Joy and Vogel 2021). As rewarding as such work is, the purpose here is to shift attention to the contingencies of progressive urbanism. By definition, progressive projects inherently seek accommodation with existing political contexts, as well as change within such contexts. Thus, the political scope of projects of progressive urbanism can be detected in the areas where accommodation with the status quo is, or is not, made. It is necessary to probe these areas, accepting that the scope of progressive urbanism projects will always be context-specific: political strategies and decisions and a lack of political capacity or will are inherently contingent. However, it is still possible to consider more general characteristics that shape projects of progressive urbanism, most notably the state, collective political organization, and the political resonance of the "local" and "urban." The following section reflects on these through a review of the rich debates on urban politics and progressive urbanism more specifically.

\section{The Contingencies of Progressive Urbanism}

The engagements of a progressive urbanism with existing structures are not set in stone, preordained, but rather the points at which the shape, scope, and success (if we want to use that term) of progressive urbanism might be determined. Cooper 
writes of the "state nexus" (Cooper 2016, 318) to capture the ways in which progressive political projects become entangled with the state in multiple and unpredictable forms of political action. It is also where we will see contingent possibilities of progressive urbanism play out. Looking across the literature on progressive urban politics, we identify the following three dimensions to explore these contingencies and understand the sources of strength and weakness in progressive urbanism projects: localism, urban movements, and municipal government.

Localism. The "local" matters as a realm of urban politics because it provides a means of embedding political decision-making within the spaces of everyday life (Magnusson 2015). The political philosopher Sheldon Wolin $(2016,377)$ understood localized, place-based political action to be fundamental to democracy. In the United Kingdom, where debate on the topic has recently been pronounced, localism is pitched as a political project to counter political centralization and foster the renewal of democratic politics through bottom-up participation (Clarke and Cochrane 2013). Often bound up with national government attempts to shift responsibility for the consequences of austerity, "Progressive Localism" was proposed as a counterbalance by Featherstone et al. (2012) through four principles: (1) the fostering of diversity and solidarity through place-based political struggle; (2) the facilitation of political agency and possibility through organizing and forming alliances in the face of a punitive neoliberal political economy; (3) the mobilization of the multiculturality of the "local," showing that the particular is not inevitably chauvinistic or racist; and (4) the aim to become part of wider struggles to challenge national and international policy (p. 179f). Cochrane (2016) has stressed, however, that the "local" has been subject to political contestation between diverse forces of the Left and Right (in the United Kingdom and elsewhere), which has shaped the possibilities of local government and civic projects.

Localism is, of course, entirely embedded in a field of constraints. Scholars in Britain have detected a "defensive localism" that seeks to prevent further damage to local government services, rather than develop a more far-reaching agenda (Skinner, Joseph, and Herron 2016). The state is indeed a key locus of localism (Cochrane 2016, 908), even if the idea and impulse for localism can be seen as originating from the aim for local self-government (see, e.g., Magnusson 2015). In the context of deeply entrenched neoliberalism, whereby central government austerity is of such severity that notions of the local community and its needs are mobilized to find ways of resisting and dealing with cuts in local services and jobs (Skinner, Joseph, and Herron 2016). Studies have shown that councilors (along with local community actors) have sought to respond creatively to the challenges they face (see, e.g., Bailey, Bramley, and Hastings 2015). Wills (2016) argues that localism can be a means of developing civic culture and democratic politics; a localism 
requiring spatial as well as institutional imaginaries and practices to move away from centralized and bureaucratic political governance. There is certainly a strong sense in both theoretically and empirically-based scholarship that local action can be generative of progressive politics. Of course, the note of caution here lies in needing to avoid the "local trap," whereby political projects assume the "local" is inherently the best scale for democratic projects to such an extent that other scales and scalar politics are ignored (Purcell 2006).

Urban Movements. Cities can be viewed as laboratories of political innovation. They provide the main sites of formal and informal politics: from the parliaments and ministries to the streets and squares. Scholars have argued that the "urban" rather than the state is the true shaper of the political landscape (Magnusson 2015), that the intensification of economic and social contradictions in cities, especially larger ones, makes them sites and stakes in struggles over capitalist accumulation and social justice (Harvey 2012), and that the increasing networks of urbanization encompassing the globe are propelling a specifically urban logic of politics (Boudreau 2017). Urban areas offer specific opportunities for progressive political action and organization due to alignments and antagonisms that occur through proximate diversity (Russell 2019), with concentrations of people, economic, and social life generating their own political dynamics (Lefebvre 2003). Urban areas are, thus, seen as crucial to progressive politics, both at an empirical level, in terms of the forms of political agency and voting patterns (Douglass, Garbaye, and Ho 2019), and at a conceptual level, as they provide a stake, source, and site for collective political action (Beveridge and Koch 2019).

There is not ample space here to do full justice to the long and productive debates on "urban social movements," "urban movements," and "right to the city" movements (see Mayer and Boudreau 2012 for an overview). Rather, the purpose of this paper is to reflect on the political potential of urban movements, where collective political organization generates forms of protest, resistance, knowledge production, and, sometimes, policy change. From the 2010s onwards, the confluence of neoliberal globalization, economic crisis, austerity, racial injustices, and authoritarian national politics has prompted increased urban political organization (Mayer 2016; 2018). Activists have been making political claims in increasingly urban registers: making appeals for a "right to the city" or in relation to particular urban spaces and urban needs such as housing and urban economic development. Urban movements have, at times, been crucial in politically framing an issue like gentrification; that is, creating a politics of gentrification and developing a field of political relations around it. They foster contingencies, argumentative positions, and alternative futures. Political strength comes from the ability to 
forge alliances across differences, for example, of class, race, and gender, creating new forms of political knowledge (della Porta 2020). Of course, even if progressive urban movements achieve scale and a certain durability, their impact on policy is unpredictable, and governments often dismiss progressive movements as improper politics or ignore them if their (more conservative) base is likely to be opposed to them. Hence, the presence of progressive political parties in government is likely to be more conducive to achieving political change. This bridging across formal and informal politics is a crucial idea in the "new municipalism," as discussed below.

The potency of collective urban action lies in its capacity to politicize an issue and/or to confront injustices, the state, and other forms of embedded power that perpetuate them. In making claims and mobilizing people in support of them, urban movements can be seen as a form of direct democracy. Immigrant rights activism is an important example that has taken root in many cities, with successes and failures (Nicholls and Uitermark 2017). Of course, the urban scale is subject to competing forces and can often be won by the Right, even in contexts with strong progressive urban politics. This was apparent in the decline of "Radical Cities" in Latin America from the 2000s onwards, where fatigue combined with renewed urban organization by the Right (Baiocchi and Gies 2019, 314). Political projects offering individualized and lifestyle choices resonate within a wider context of increasing the commodification of inner cities (Keil 2017). Further, rising housing prices and austerity measures (Gillespie, Hardy, and Watt 2021) displacing and dispersing lower-income urbanites to the edges of cities can disrupt the social bases from which urban movements draw their support.

Municipal Government. Within political theory, municipalism is seen as a form of local self-government in which democracy is pursued through the decentralization of power and the possibility for political participation (Kohn 2003, 130). In practice, from the late nineteenth century to the mid-twentieth century, municipalism entailed municipal control over political and economic resources, commonly water and energy supply networks mostly in Europe and North America (Thompson 2021). Discernible was a more collectivist strand of "municipal socialism," or gas and water socialism, and a "municipal enterprise" strand, where local authorities acted very much like private markets (Leopold and McDonald 2012, 1840). Within this longer tradition, the so-called "new municipalism" is a diverse and still emergent political project. Looking across the various documents published by key centers of "new municipalism" (e.g., Barcelona), as well as journal articles (Russell 2019; Thompson 2021) and "house" websites, such as www.minimmunicipalism.org, the overall aims of "new municipalism" might be summarized as that of transforming democracy from representation to participation 
and politics from parties and institutions to citizens and projects. Thompson (2021) has identified the ongoing urban crisis following the Global Financial Crisis as pivotal to the emergence of the "new municipalist" projects, triggering progressive ambitions and strategic concerns for gaining political office after the exhaustion of activism in the face of relatively unchanging political-economic conditions (e.g., of austerity and racism), especially in Greece, Spain, the United Kingdom, and the United States.

The "new municipalism" is both pragmatic and ambitious in its attempts to become a political "binary-buster" (Beveridge and Featherstone 2021, 447): working across boundaries between social movements and political parties, direct and representative democracy, the state, and urban everyday life. "Movement Parties" (della Porta 2020, 22) such as "Barcelona En Cumo" are emblematic of such an approach to broaden the project of municipalism. Antecedents are also apparent: the "Progressive Cities" in 1980s United States, notably Chicago and Boston, also became witness to activists in city hall as a progressive response to the Reagan Presidency, to paraphrase the title of Clavel's (2010) book. Activists were also prominent in the left Labour Councils of 1980s England in London and Sheffield, for example, (Boddy and Fudge 1984). In contemporary United States, the movement "Cooperation Jackson" has developed a strategy of dual power, creating cooperatives as bases of autonomous economic power for Black communities in Jackson, Mississippi, while also-at least until recently-engaging with the mayorship of Chokwe Antar Lumumba. This project also has echoes of the Black Power movements of the 1960s and 1970s, which sought empowerment through taking control of neighborhoods and economic and cultural institutions, though also sometimes through engaging with the government (see, e.g., Self 2003 on Oakland).

The primary contingencies of the "new municipalism" lie in the limits of political projects hinged, however loosely, to governmental offices. Progressive forces will always at some point struggle to maintain momentum and achieve change given the nature of formal politics and the state. Davies (2021) offers sober reflections on the achievements of progressive urban movements emergent in the wake of the Global Financial Crisis of 2007-2008, highlighting the difficulties even projects like "Barcelona En Comu" have encountered in terms of implementing progressive policies like remunicipalization. Of course, the "new municipalism" seeks to go beyond the institutions of the state, seeking a base in social movements. Nonetheless, it remains subject to the need to have a foothold in state institutions. Janoschka and Mota (2020) ask how far the progressive government in Madrid (2015-2019) was able to free itself from the neoliberal paradigm before also losing political office and momentum. More fundamentally, Rossi (2018) makes clear that we should not assume that urban and municipal 
politics are essentially progressive, with his analysis of the urban dimension of right-wing populism in Italy, which exists alongside examples of progressive "new municipalism" in, for example, Naples.

The three dimensions outlined above constitute general ways to consider the unfolding of projects of progressive urbanism, their contingent resources, strategies, and scope:

- Localism as a democratic project, whereby place/locale, can generate progressive alliances and participative politics. However, projects must be attuned to scalar politics and the potency of conservative imaginaries of the "local."

- Urban movements can (re)set political agendas, provide voices for marginalized groups, and develop new forms of political knowledge. However, movements can often be particular and struggle to forge broad and durable alliances, which impedes their impact on governmental decisions.

- Municipal government, in its current "new municipalist" iteration, appears to offer a means of bridging progressive political parties and movements to transform the way politics are done (more direct democracy, less representation), as well as the aims of politics. Despite achievements in places like Barcelona, the difficulties of working in and between formal politics and movement politics remain apparent.

Thus far, we have considered progressive urbanism only in general terms. In the following section, we consider how small towns fit into the relevant debates.

\section{Searching for the Small Town in Progressive Urbanism}

When urban scholars and activists are searching for the "Progressive City" (e.g., Joy and Vogel 2021), they are usually not looking for it in relation to small towns. As we argued above, the progressive urban imaginary is populated by examples of larger metropoles. Paris in the past, Barcelona or Porto Alegre more recently-these are cities with populations of well over a million. Yet, large size, urbanity at scale, does not quite denote progressive potential, there is a certain sense that smallness denotes political conservatism or deficit.

Following Bell and Jayne (2009), we define a small town as one with a population of up to about 50,000 inhabitants. However, this is not a rigid classification because "smallness" is not derived from size alone but can also be discursively shaped. As Bell and Jayne (2009, 689ff) discuss, a sense of smallness may be derived from a lack of centrality—of geographical location 
(e.g., on the periphery) or political-economic status within regional and national contexts.

Small towns rarely make an appearance in discussions on progressive political transformation - they have rarely been center stage in leftist politics in the Global North. In the U.K. context, a "new urbanism of the left" has become apparent for some (Cruddas 2019), in which a broadly progressive politics centered on younger and more professional urbanites resident in larger metropolitan centers pulls away from an older working-class leftism located in - and increasingly prone to becoming - the conservative backwaters of the small towns and suburbs. Such analyses align with the discourse on the winners and losers of globalization, particularly in terms of deepening regional inequalities, whereby small towns and rural areas in the Global North are seen as the spatial losers in terms of innovation, in-migration, and productivity (Iammarino, Rodriguez-Pose, and Storper 2018). Politically, small towns have become associated with the reactionary populist right, while larger towns tend to be the "winners" in globalization and are seen as progressive and left-leaning. While these generalized statements are questioned in current debates (e.g., Förtner, Belina, and Naumann 2021), the dichotomy between "Progressive Cities" and a reactionary hinterland remains powerful in media and political discourses.

Small towns have been generally overlooked within urban studies, perhaps viewed as uninteresting, provincial, or conservative (Bell and Jayne 2009). Indeed, there is a parallel between debates in urban studies generally and debates on progressive urbanism: a constant focus on the novel conditions of urbanity and progressive urban politics leads the researcher to large cities (ibid., 685). This big city lens aligns with the sense that small towns, at least in the Global North, are always facing problems or are themselves part of a wider problem (like right-wing populism).

This neglect seems odd when we consider the political importance of small towns; there are, quite simply, rather a lot of them, and successful progressive politics in these places would make a tangible difference. For example, close to a third of the U.S.'s population (about 40 million) lives in towns with between 10,000 and 50,000 inhabitants (Clancey 2004 in: Bell and Jayne 2009, 689). Hence, the relevance of the U.S. campaign organization "People's Action" aims to develop multiracial working-class coalitions in small towns and rural areas (People's Action n.d.). There are further examples of progressive urbanism in small towns. The historical example of "Debsian Socialism" (named after one of the figureheads of the socialist movement in the United States, Eugene V. Debs), provides a good starting point, with its strong support, not in the major cities, but in small towns and rural parts of the country in the early years of twentieth century (Burwood 2003). We see something similar in the much more recent success of progressive left 
and green "new municipalists" in the French 2020 local elections (Dau 2020). Such results do not seem to prompt wider consideration of small towns as contexts of progressive politics. Further, there is a tendency in academia and the activist discourse to blend out the spatial and political particularities of better-known examples of progressive politics in smaller places. A good example is the small German town of Wolfhagen. With a population of around 13,000 , it is held as an exemplar of remunicipalization and publiccommunity partnerships (Milburn and Russell 2018), but its size and particular political-economic composition are rarely considered in analyses.

The political imaginary of the small town tends, at least in popular culture in the United States, to be saddled with conservativism, evoked in the notion of "small town America." However, there are some examples of progressive small towns in the United States. A key example is Burlington (Vermont), with a population of around 40,000, where Bernie Sanders was mayor (1981-1989), and the Progressive Party is still strongly represented. Perhaps the closest we come to a leftist imaginary of a small town, would be that of the "Little Moscows," a term used during the Cold War to denote communist party strongholds in-usually—small industrial towns in Europe, such as Seraing (Belgium), Halluin (France), and Mössingen (Germany) (Knotter 2011, 476), as well as the former mining community of Lumphinnans in Scotland. There have also been smaller towns associated with periods of more broadly progressive urbanism, such as Walsall in the "New Urban Left" movement of 1980s Britain (Boddy and Fudge 1984), though predictably perhaps, it received much less attention than the larger cities of Liverpool, London, and Sheffield.

Overall, there is a lack of research on contemporary cases of progressive urbanism in small towns: how the particular conditions of small towns may shape the development and scope of left progressive politics and how they compare to other urban places, such as the large metropolises. Again, there are parallels with the more general lack of research on small towns and Bell and Jayne $(2009,690)$ are correct to argue ". . . that there is a clear need to look in detail at the actual political, economic, social, cultural, spatial and physical nature of small cities rather than judging them simply with reference to theories and measurements developed with reference to big cities and metropolises." This means not viewing small towns through the "big city lens," and only in the negative, in terms of a possible absence, for example, of urbanity and the political resources that might stem from this.

In short, it is necessary, in the first case, to develop empirical insights on progressive urbanism in small towns to develop a general sense of political principles, projects, and contingencies. From this, more conceptual and strategic reflections on the scope and potential of political projects become possible, as does a wider sense of how progressive urbanism varies across urban 
contexts. We apply this approach to the case of small towns in the German state of Brandenburg governed by the Left Party.

\section{Progressive Urbanism in Small Towns in Brandenburg (Germany)}

In September 2019, just before the last state elections in Brandenburg, the British Observer ran the headline "Far-right AfD bids to encircle Berlin as resentment and division grow" (Connolly 2019). The article laid bare the metropolis-hinterland binary mentioned above: the politically progressive metropolis, Berlin, under threat from the politically reactionary hinterland of Brandenburg surrounding it. To get beyond such binaries, interviews were conducted with mayors representing the Left Party in seven small towns in the German state of Brandenburg. This work was a deliberate step away from a "center" of progressive urbanism. Berlin is seen as an "activist city" (Beveridge and Naumann 2016) and one subject to considerable academic interest in debates on progressive urbanism (e.g., Hamann and Türkmen 2020; Beveridge and Koch 2021; Holm 2021). By contrast, there is a notable lack of work on progressive politics in Brandenburg.

Brandenburg has a slightly increasing population of 2.5 million people (Statistische Ämter des Bundes und der Länder 2020), with only two cities with more than 100,000 inhabitants (Potsdam and Cottbus), growing municipalities in the suburban belt around Berlin, and sparsely populated regions further away. The towns selected for our interviews (see Figure 1) vary in terms of their size-from Frankfurt (Oder) with around 50,000 inhabitants to the municipality of Wiesenburg (Mark) with only around 4,200-as well as in their distance to urban agglomerations-from the suburban town of Bernau to the small town of Templin, which is located in the northern periphery of Brandenburg. Another important political issue in Brandenburg as well as in many other parts of Germany was the increased arrival of refugees in 2015, which generated numerous cases of racist public debates and campaigns. Cities like Cottbus became locations of regular, sometimes violent mobilizations of the far-right (Fröschner and Warnecke 2019). The political party of the far-right, the Alternative für Deutschland (AfD), became the second largest party in Brandenburg (Landeswahlleiter Brandenburg 2020) in 2019, claiming 23.5 percent of the votes in state elections. Within this context, the Left Party remains prominent, but has lost its once strong base in the region. The Left Party was part of the state government from 2009 to 2019. However, the party's share of the electoral vote fell from 27.2 percent in 2009 to 10.7 percent in 2019. The party also lost a number of mayorships and seats in local parliaments (Landeswahlleiter Brandenburg 2020). 


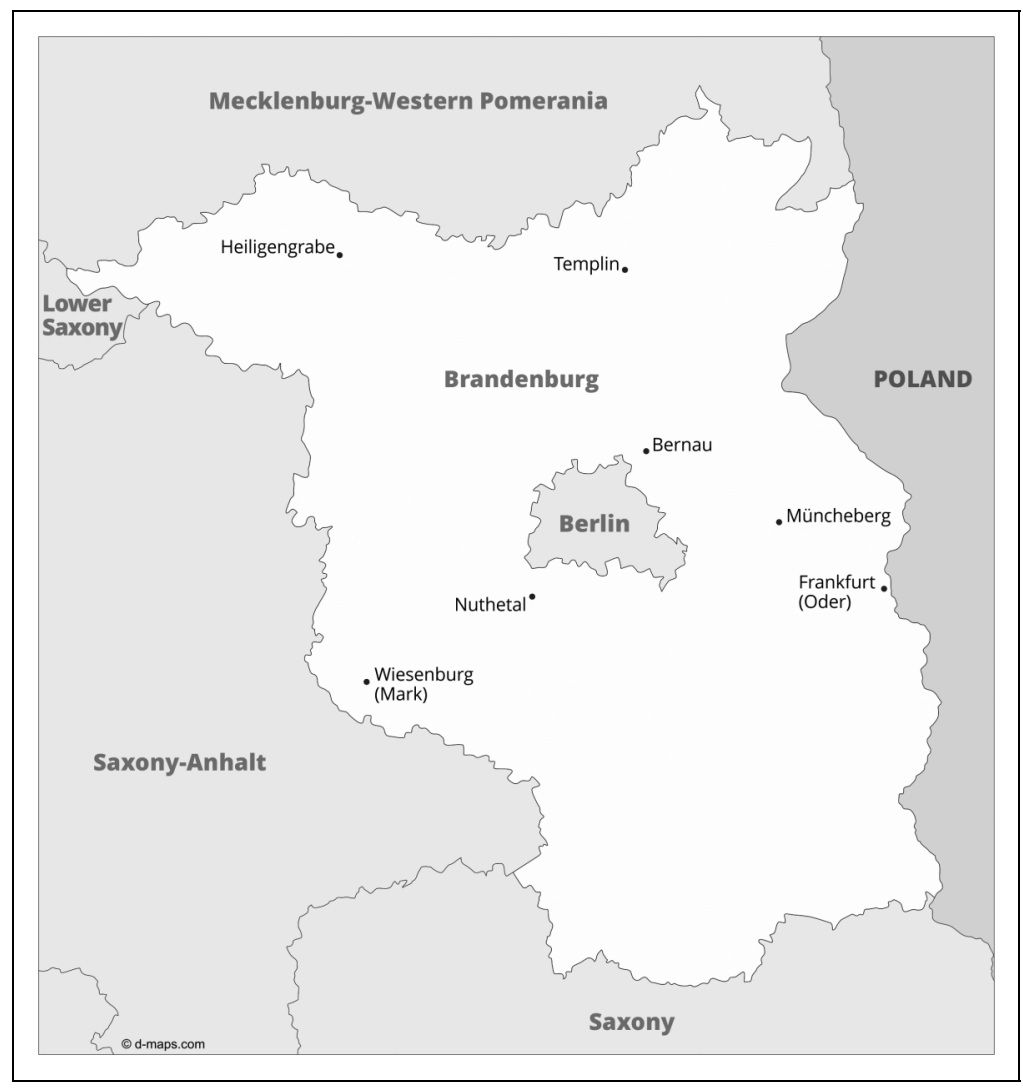

Figure I. Map of municipalities with full-time mayors from the Left Party (DIE LINKE) in Brandenburg.

Source. Own presentation.

Due to restrictions imposed by the COVID-19 pandemic, all interviews were conducted by video chat in German, transcribed, approved by the interviewees, and translated into English. The authors of this paper are not members of the Left Party but do have connections to some of its members and representatives, which helped in gaining access to the mayors. A qualitative content analysis (Mayring 2004) of the interviews was conducted. Focusing on formal politics, of course, limits the perspective on, and understanding of, progressive politics in small towns. There is a reliance on the politicians themselves to the exclusion of other voices. Nonetheless, the focus on leaders of local government is justified given its continued importance as a locus of political activity (Cochrane 2016, 908). A further benefit of interviewing the mayors was to 
generate empirical findings on the politics of the Left Party in local government, thereby, contributing to recent debates that have become increasingly critical of the party's role in government (Holm, Lederer, and Naumann 2011; Wolf 2016).

The main purpose of the interviews was to discover how the mayors viewed the challenges and opportunities of progressive politics in their particular small towns. From this, it would then be possible to reflect on progressive urbanism in these small towns and link back to debates on the potential of localism, urban movements, and municipal government. We structured our interviews around three themes to achieve this. To avoid the adoption of a "big city lens," our first step was to ask the mayors themselves to outline what they considered to be the main principles and priorities of progressive politics in their particular contexts. Interviews were approached with the maxim of allowing mayors to "speak for themselves while maintaining a critical distance" (Cochrane 1998, 2131). The aim here was to get a sense not just of their policy priorities and overall strategies, but also more fundamental understandings of local democracy and progressive or left politics. This line of questioning was most relevant to understanding the dimension of localism as a democratic project. Second, they were asked about the realization of these principles and with which partners or networks they were able (or not) to work with. This provided the opportunity to discover the extent to which they were involved with movements or other political organizations, in "new municipalist" type arrangements, as well as the extent to which they worked beyond their areas "horizontally" (with other small towns) and "vertically" (with regional and national political scales). Third, the mayors were asked to detail the main political challenges and barriers to progressive politics in their small-town contexts. This was relevant to understanding the contingencies of the three dimensions and the importance of wider contextual issues, such as austerity.

\section{Progressive Urbanism in Small Towns in Brandenburg}

Looking across the interviews, we identified five common principles that all mayors in some form prioritized. First, anti-racism: the mayors emphasized a commitment to "fight against any forms of prejudice and intolerance" (Interview 1). This was no doubt a reflection of the increasing support for the AfD across the region. Alongside this was, second, a clear commitment to what we might call the public good: ". . . the inhabitants of the town are the owners of the town" (Interview 3). None of the mayors directly mentioned local democracy nor referred to societal pressure to promote it, rather, the general aim was that of governing for all; a politics that creates benefits for as many people as possible. Third, social inclusion was nonetheless a priority to "make sure that nobody is forgotten" (Interview 7) in the development of 
the town. The mayors displayed, fourth, a commitment to transparency in communication and decision-making, with many noting that a mayor in a small town is a well-known figure and often approached by residents in everyday situations, such as on the street or in the supermarket. As one mayor put it: "For me, the bottom line in dealing with everything and with all the issues is honesty, honesty, and once again honesty" (Interview 5). Fifth, ecological sustainability was mentioned frequently and is important given that the towns are in a rural region characterized by forests and lakes, along with intensive agricultural use.

These principles might be read as fairly standard for a progressive politician. They are also in part reflective of the context in which they work (e.g., dealing with the threat of the far-right and the rurality of surrounding areas). More striking, is the refusal to be characterized as explicitly or solely left-wing mayors: "I want, and this is currently also the case, that somebody who did not vote for me or would never vote for the Left Party, knows he is able to address the city's administration with his ideas, critique, and problems" (Interview 1). For some mayors, this approach was linked to the regional context, the shared problems facing municipalities in Brandenburg, which in their opinion made differences between political parties less relevant than in other places (Interview 5). Scale was also pertinent in their view, with one mayor stating that politics at the local level was often about very specific problems, which again rendered general political party programs and policies less important (Interview 4). The same mayor went as far as to say, "I don't really use the term left-wing local politics every day" (Interview 4), elaborating that there "are challenges that affect us here, particularly in the region, as a rural area, which I basically cannot solve with exclusively left-wing local politics" (Interview 4).

The pragmatic, in a sense almost depoliticizing, approach places very clear distance between the mayors and the much more politically overt cases of progressive urbanism, for example, in places like neighboring Berlin, where politicians of the Left Party regularly display progressive ambition and critique existing structures. The mayors were not entirely distanced from wider strands of urban political movements, even if their knowledge was patchy: "I am familiar with the 'right to the city' debate, but could you explain what you mean exactly by municipalism?" (Interview 1). This shows some of the limits of the "new municipalist" project. The broader point to make here is that all mayors interviewed eschewed what we might call "big" narratives or terms like "socialism," "left," or "progressive" politics. Interestingly, they also did not refer to the wider program of the Left Party, its main debates, or the key policies of its think tanks like the Rosa Luxembourg Foundation. The message is clear: for these Left Party small-town mayors, politics is not about expounding progressive political visions and wider movements but is about local projects with concrete aims and 
outcomes: "As a municipality, it is our job, to provide good living and working conditions for the people here" (Interview 2). This statement could be read as an alternative definition of what municipalism means in the political contexts of these small towns.

\section{Projects and Networks of Progressive Urban Politics}

The concrete projects and networks through which the mayors attempted to realize their projects, was the second theme discussed in interviews. Projects of anti-racism refer mostly to the accommodation of refugees. The 2015 "Summer of Migration" in Germany led in many parts of Brandenburg to racist protests against the provision of shelter for refugees. The mayors made clear their support for the accommodation of refugees throughout the town, instead of in concentrated housing that is often located on the outskirts. For instance, one municipal housing company allocated every fourth apartment to people with a migration background (Interview 6). Furthermore, many of the mayors had been involved in local "welcome initiatives" for the refugees aimed at fostering integration and preventing hostile reactions (Interviews 2, 6 , and 7). One mayor established a collaborative initiative with local business associations to promote employment and education opportunities for refugees (Interview 3).

Projects addressing the public good included the remunicipalization and redevelopment of abandoned buildings formerly hoarded by private owners for tax reduction purposes (Interview 1). A strong position against the privatization of public companies was apparent and underscored the establishment of a special-purpose public association for the digitalization of municipalities in Brandenburg (Interview 6). One town mayor introduced a participatory budget allowing citizens to decide directly about a certain share of the municipal finances (Interview 1). An important issue for many mayors was dealing with the recent growth of Berlin and the in-migration of Berliners looking for cheaper property and more space: "We do not want to attract as many inhabitants as possible and become a suburb of Berlin. Instead, we want to develop our own faceted urban life with free spaces for creative development" (Interview 2).

Social inclusion was a priority for all mayors, who claimed to spend a large proportion of their budgets on social projects, such as the provision of universal childcare; hiring of social workers in schools; and the renovation of municipal-owned flats, schools, sports facilities, and kindergartens. A notable project was a town "passport" that provides low-income households with discounts on the use of cultural facilities. Social inclusion was integrated into the housing policy, which, as one mayor put it, "is not about creating attractive spots for high-income groups at the expense of all others" 
(Interview 1). This challenge was especially strong for those towns experiencing rapid growth, led by an influx of Berliners (Interview 2). A number of towns introduced support programs for young families to build their own homes and provided funds for the municipal housing company to build new homes with affordable rents (Interviews 4, 6, and 7). Child poverty was another concern mentioned by several of the mayors. One town initiated a "roundtable against child poverty," to help coordinate different programs and actions, while others provide childcare programs for school pupils from socially disadvantaged families. Due to the demographic developments in Brandenburg, with an increasing share of older people, the care elderly people need is increasingly an issue of social inclusion in all towns we considered. According to the interviews, the impact of COVID-19 is likely to exacerbate existing social polarizations in the municipalities.

Transparency projects included the use of new digital media channels such as podcasts, videos, digital office hours, and online streaming of meetings of the local parliament. Other projects include neighborhood tours and citizens' assemblies. In the more rural municipalities, the mayors organized regular resident meetings in all parts of the town (Interview 7). Ecological sustainability projects included the creation of new common green spaces: "We do not try to fill every space between buildings but invest in extensive public parks" (Interview 2). Further examples include the installation of photovoltaic systems and the protection of water resources (Interview 6). The introduction of electric cars and the creation of new bicycle paths (Interview 6) were also highlighted. Several mayors noted attempts to increase the attractiveness of public transport, e.g., through the introduction of a ticket-free public bus system (Interview 3), the reactivation of train routes (Interview 3), efforts to establish a regular train connection to Berlin (Interview 5), and improving bus connections to rural districts (Interview 6).

The mayors were aware of the small-scale character of their projects, but saw this as a strategy for change, "But I really think that these projects, which are missing in other cities, make a difference" (Interview 1) or, as another mayor put it, "Thus far, big politics did not play a role in the local parliament, but rather the work on concrete issues" (Interview 3).

Realizing such projects obviously requires building networks and coalitions with local partners. As mentioned above, party politics are seen as less important in the small-town context of Brandenburg. With around 5,200 members at the end of 2020 (DIE LINKE Landesverband Brandenburg 2021), most of whom are elderly, the Left Party's personal resources are very limited. Therefore, the implementation of projects really depends on developing relationships with other local actors (Interview 3).

The relative lack of importance of political parties is illustrated by the fact that only one of the seven interviewed mayors mentioned one party (the 
Greens) as being an important political ally (Interview 6). Instead, the political networks described in the small towns extend far beyond the "usual suspects" of progressive urbanism, such as urban movements or trade unions (Mayer 2013). In the more rural municipalities, collaboration with lower levels of government, such as the village provosts, was seen as key for the successful realization of projects (Interviews 3, 4, 5, and 6). Beyond the governmental realm, other important partners mentioned by the mayors were key players in the local economy, such as the chamber of industry and commerce or business associations. Most surprisingly, perhaps, local churches, sports clubs, the chess club, fire brigade associations, local culture associations (Heimatvereine), and social associations (Volkssolidarität) were also mentioned as being part of networks for realizing local policies. The heterogeneity of coalition partners necessitates a pragmatic open approach to politics (Interview 7): "we are a small town, I must say. Things are a bit different and more relaxed" (Interview 5). Regional networks within the Left Party in Brandenburg did play a role, if not a central one. Although regular meetings were more about common issues to be addressed at the Brandenburg state government level and less about projects in each town, they did provide an opportunity for the exchange of knowledge and experiences. Unlike other political parties in Brandenburg, the Left Party allows local mayors a fair degree of autonomy. These regional networks have, however, been affected by the overall decline of the Left Party in Brandenburg, with fewer members, fewer votes, and fewer mayors across the state, resulting in smaller party networks and increased isolation (Interview 7). Beyond the region, mayors had very few exchanges with other left mayors in Germany, stating that there was a lack of a coordinated exchange of information.

\section{Challenges to Progressive Urbanism in Small Towns}

The perceived challenges can be summarized in terms of general difficulties for municipalities in Germany, those specific to towns in Brandenburg, and those related to the Left Party.

General challenges include the financial restrictions faced by municipalities in Germany because of austerity politics, most notably the reduction of financial budgets (for a detailed description, see Petzold 2018). Our interviews illustrated that austerity works not only as a financial limitation upon the scope of policy-making, but it also shapes a discourse of balancing budgets and decreasing possibilities. Financial restrictions here led to a situation in one town where ". . . big dreams are not possible, and we have to look for options that do not require financial resources" (Interview 1). Problems of public funding, as well as demographic change, combine and result in, for instance, a reduction of public transport that especially affects the elderly 
(Interview 7). Austerity politics are another driver of the merging of municipalities. As a result, there are municipalities covering huge areas, up to a quarter of the area of Berlin, for example, but with only several thousand inhabitants (Interview 4). Further, general challenges include the "jungle of laws in federal and state politics" (Interview 3). According to the mayors, it is very difficult for small towns and rural municipalities to locate the requisite time and knowledge resources to cope with bureaucratic processes, especially in environmental and construction law. This has made urban development projects extremely complex and slow.

Issues specific to the Brandenburg region include the impact of urban sprawl around Berlin and the first signs of rural gentrification. All mayors noted a growing pressure on housing markets, as increasing numbers of people move out from Berlin due to the higher cost of living in Berlin or their desire for a weekend house (Interviews 3 and 4). Resulting rises in real estate prices is leading to an affordability crisis in rental and housing prices in the region and tensions between incomers and longer-term residents (Interviews 3 and 6). Immigration has been another key issue in Brandenburg, a state with only 5 percent of non-German citizens in the total population in 2018 (Landesamt für Bauen und Verkehr 2020, 3). The mayors were clear about the presence of the far-right and antiimmigration sentiments in their towns (Interview 3). Their analysis of the AfD's members and voters differed. One mayor reported that "classical conservatives" were the activists of the AfD in his town (Interview 3). For another mayor, the AfD was strongest in the most remote parts of the municipalities with the worst connections to public transport and shopping facilities (Interview 7).

The mayors also identified challenges arising from the Left Party's decline in support, which has resulted in it no longer being in the coalition government at the state level. This has resulted in reduced government contact and access to information (Interview 1), as well as a change in the broader regional political context: "the fewer votes we get at the state and federal level, the fewer members of parliament we have who can stand up for our cause" (Interview 7). Internal party conflicts have increased, also in their own local branches: "Yes, it sounds really stupid when I say that my leftwingers are the biggest opponents of my politics" (Interview 7). This mayor saw conflicts emerging from the sometimes utopian demands of the local party members and the limited financial possibilities of the municipality. In general, the party also has very few members and resources-few activists who go out and do the work of canvassing and so on.

The identified common principles of leftist small-town politics, the projects realized, and the networks, as well as the constraints on progressive urbanism can only be understood with reference to the regional context of 
Brandenburg. Nonetheless, the interview findings raise more general issues about the contingencies of progressive urbanism.

\section{Discussion: Contingencies of Progressive Urbanism in Small Towns}

In this section, we draw the interview findings into dialogue with the three dimensions of progressive urbanism outlined earlier: localism, urban movements, and municipal government as contingent sources of political capacity. This throws into relief key differences between general debates on progressive urbanism and the ways the mayors accounted for their work in the context of small towns in Brandenburg. Key points include the importance of local coalitions, of "small" political projects, and of traditional municipal politics.

\section{From Translocal Movements to Local Coalitions}

The interviews showed the importance of broad networks for the realization of local projects. Considering the budgetary restrictions of municipalities and their dependence on state, federal, and European funding, the room for maneuver is rather limited, and even modest political projects entail sometimes hard and long struggles. Within these contexts, local partners, from churches to chess clubs, were identified as crucial. This illustrates the ability of the mayors to gain broader support for their versions of progressive politics and involve people who are not connected to the Left Party. It also underscores the marginal importance of activists, such as urban movements, NGOs, and trade unions. Indeed, the mayors noted that other Left Party mayors and the wider organizational structure of the party were not of great importance. None of the mayors mentioned national or international contacts with other left mayors in office. A network of "Fearless Cities," "Radical Cities," or even cities with left-leaning governments in Germany does not exist. Perhaps, this reveals that translocal solidarity and networks are also a matter of resources - of time available, of language skills, funding for traveling-all of which are very limited in small towns experiencing systematic budgetary cuts. Hence, the work of building local coalitions is essential, even if wider networks would offer a greater range of resources.

Localism is fundamental to these political projects, developing alliances around local issues and relationships. Yet, the very local scope of politics entails the risk of a conservative localism and the local trap, where projects fail to address wider scalar and spatial dimensions of problems (Purcell 2006). The former was apparent in a number of statements that made a 
clear distinction between "we" (the people who had lived in the town for a while) and "they" (the people moving into the town, either from Berlin or as refugees). Of course, the increasing interrelations between the small towns in Brandenburg and the metropolis of Berlin and the wider world provide grounds for increasing translocal networking. Gentrification and displacement are no longer only an issue of Berlin's inner-city neighborhoods but have an effect on the housing market in small towns in Brandenburg as well. Therefore, there is both potential and a need for collaboration between small and large town projects of progressive urbanisms.

\section{From Political Paradigms to Small-Scale Projects}

All interviewed mayors emphasized the importance of concrete undertakings in their municipalities, such as housing programs for young families, community centers in villages, and investments in public transport. These projects were realized under sometimes difficult financial or juridical conditions. However, a sense of a wider political program beyond individual projects was missing in the majority of the interviews. While we might not expect the mayors to mention debates like the "right to the city" or "new municipalism," the reluctance to engage in an articulation of progressive politics more generally, revealed a dominant pragmatism. The absence even to link to federal, state, or national programs or debates of the Left Party suggested a distancing from a wider progressive political agenda and foundational debate, and an emphasis on the daily struggle to get things done.

\section{From "New Municipalism" to Traditional Municipal Politics}

Being a local politician elected for a party appeared to provide both an opportunity for, and an obstacle to, political change. The mayors were generally very clear that they were governing for the whole town and that local problems, and the nature of small-town politics, make more general political differences less important. Of course, such an approach makes sense in electoral terms when one is seeking to become or remain mayor. However, there is an obvious risk that progressive politics get lost in these machinations; that electoral success blends out a desire to engage with issues that involve confronting important local actors. It might also risk not reaching out to and building alliances with overtly progressive actors, bringing them into the realm of formal politics, as "new municipalist" projects seek to do. While one mayor did refer to a participatory budgeting policy, wider attempts to transform the local state were not apparent. The lack of urban movements applying pressure for progressive change may be seen as a factor here. All mayors talked about civic engagement and the potential of local organizations 
to push projects forward, yet the lack of a wider progressive constituency must impose some limits in terms of the scope of political thinking.

In summary, it is clear that debates on progressive urbanism need to engage more thoroughly with the contingencies of small towns in places like Brandenburg. The local scale and small projects remain important and can make a difference, despite their often limited and pragmatic character. As shown, small towns - and not only large towns-also have to address "global" issues of migration, demographic change, social inclusion, and climate change. There is arguably less knowledge support and resources for them to do so, given their marginal position in the wider national governmental system and networks of progressive urbanism. Therefore, progressive urbanism in small towns may be more dependent on developing closer ties within left political parties, utilizing the wider networks of resources they provide. Furthermore, our insights from progressive urbanism in Brandenburg reveal that localism, urban movements, and municipal government have quite ambivalent meanings in this specific context.

\section{Moving the Debate Forward on Small Towns}

More detailed and comparative research on small towns in diverse contexts is necessary to probe these findings and distinguish between generic and particular contingencies of progressive urbanism in small towns. The three dimensions-localism, urban movements, and municipal government-draw on debates in the fields of urban studies and offer ways of thinking about how progressive political projects are conceived by protagonists engaging with specific spatial contexts. They also offer the researcher a possible means of conducting comparative research, as well as locating particular projects within wider academic debates. Cases for comparative research could include other small towns in the Global North that are also experiencing suburbanization, austerity, and an increasing far-right presence similar to that observed in the towns in Brandenburg. It would be fruitful to look for cases where progressive political parties, despite a general crisis, can still hold town halls, for example, in France or Italy. It would also be of interest to look at cases where progressive political projects chose new structures that do not rely on an existing party, e.g., the broad coalitions of "Movement Parties" in Spanish cities and look at how these coalitions work in small towns. Finally, we also revealed the limits of a political approach that is narrowed by administrative borders, e.g., between big cities and the small towns in their hinterland. Future research might locate projects of progressive urbanism focused on building alliances between cities, towns, and rural municipalities. 
The review of the literature conducted here revealed there is no real contemporary imaginary of progressive small-town urbanism. Indeed, for many, small towns might be a short-hand for political conservatism, populism, and socioeconomic problems. For precisely these reasons, there is a need to conduct further research on small-town progressive urbanism. This paper has touched upon issues of dealing with the far-right and racism in relation to Brandenburg. Future research should engage with other local contexts, with the aim of detailing patterns of progressive strategies, practices, and visions. Such work is crucial to show the possibilities for dealing with the farright and developing responses in places too easily and quickly considered as "lost" to progressive politics. It is also crucial to gain a sense of how progressive urbanism operates over time in small towns and, more generally, beyond the centers of urban activism. Ongoing weaknesses in progressive urbanism in small towns would also be revealed through such comparative research. The findings from Brandenburg showed a distance between "big" theories and slogans like "New Municipalism" and the political projects of the mayors. More in-depth research in the future might help facilitate dialogue between these aspects or might encourage them. All this can contribute to developing progressive imaginaries of the "local," as well as effective policies and strategies, and to avoid conceding ground to reactionary forces of the right.

\section{Conclusion}

Can city governments be a force for progressive change? This was the question we asked at the beginning of this article. Ralph Miliband (2009), writing in the 1960s, thought it is impossible to achieve transformative change through simple participation in the institutions of liberal democracy in Britain, such was the hostility of the state and the entrenched power structures centered on capital and privilege to which it was beholden. Miliband was writing about national politics, but the literature on urban politics has devoted considerable time to detailing constraints on political maneuver. Most notable, perhaps, is the literature on "Urban Regime Theory" pioneered by Clarence Stone (1989) to capture how public and private interests align in informal governing arrangements and become dominant. Contemporary engagements with "Urban Regime Theory," like that of Davies (2021) on urban governance since the 2010 s, also emphasize the straitjackets on progressive politics and urban politics generally, be they austerity, the limits of social movements or coalition government, the power and hostility of (supra)national government to city governments, and the capacity of global economic players to make or break places through their locational and investment decisions. 
The research conducted on the left mayors in Brandenburg provided a limited but still illuminating view of what might be seen as a Realpolitik of progressive urbanism. Constraints on political action were, of course, apparent, especially in relation to austerity. By definition, progressive political projects will always exist as calculations of what is and is not possible in a particular place and time. They will take shape through trial and error, attack and retreat; be a mix of rhetoric and realism. The question for researchers and practitioners of progressive urbanism is whether they can better locate the alignment of political strategies and social-economic conditions in which things progress politically. There will, of course, be no single or generic project of progressive urbanism. As argued here, however, a concern for localism, urban movements, and municipal government provides a means of reflecting on the contingencies of governing the town or city from the left. These dimensions may also provide a useful way of comparing the potential and limits of projects of progressive urbanism across very different urban contexts. Overall, it is hoped that they may help researchers in the challenge of identifying those alignments of spatial context, political strategies, practices, and visions that forge openings in diverse urban settings.

\section{Acknowledgments}

The authors would like to thank the seven mayors that participated in interviews for this research. They also thank Louisa Petzold for transcribing the interviews conducted, Ramona Winter for creating the map, Felicitas Kübler and Michael Mießner for comments on an earlier version of this paper, and Mary Beth Wilson for conducting the final copyediting. Much of Ross Beveridge's work on this paper was funded by an Urban Studies Foundation Senior Research Fellowship at the University of Glasgow.

\section{ORCID iD}

Ross Beveridge (D) https://orcid.org/0000-0002-1121-7083

\section{References}

Bailey, Nick, Glen Bramley, and Annette Hastings. 2015. "Symposium Introduction: Local Responses to "Austerity."” Local Government Studies 41 (4): 571-81. https://doi.org/10.1080/03003930.2015.1036988.

Baiocchi, Gianpaoplo, and Heather Gies. 2019. "Radical Cities in Latin America: Past and Present." NACLA. Report on the Americas 51 (4): 313-15. https://doi.org/10. 1080/10714839.2019.1692908.

Bell, David, and Mark Jayne. 2009. "Small Cities? Towards A Research Agenda." International Journal of Urban and Regional Research 33 (3): 683-99. https:// doi.org/10.1111/j.1468-2427.2009.00886.x.

Beswick, Joe, and Joe Penny. 2018. "Demolishing the Present to Sell Off the Future? The Emergence of 'Financialized Municipal Entrepreneurialism' in London." 
International Journal of Urban and Regional Research 42 (4): 612-32. https:// doi.org/10.1111/1468-2427.12612.

Beveridge, Ross, and David Featherstone. 2021. "Introduction: Anti-Politics, Austerity and Spaces of Politicisation." Environment and Planning C: Politics and Space 39 (3): 437-50. https://doi.org/10.1177\%2F23996544211004188.

Beveridge, Ross, and Philippe Koch. 2019. "Urban Everyday Politics: Politicising Practices and the Transformation of the Here and Now." Environment and Planning D: Society and Space 37 (1): 142-57. https://doi.org/10.1177\% 2F0263775818805487.

Beveridge, Ross, and Philippe Koch. 2021. "Contesting Austerity, De-Centring the State: Anti-Politics and the Political Horizon of the Urban." Environment and Planning C: Politics and Space 39 (3): 451-68. https://doi.org/10.1177\% 2F2399654419871299.

Beveridge, Ross, and Matthias Naumann. 2016. "Contesting Neoliberalism in an 'Activist City': Working Towards the Urban Commons in Berlin." Soundings: A Journal of Politics and Culture 64: 88-93.

Blanco, Ismael, Yunailis Salazar, and Iolanda Bianchi. 2020. "Urban Governance and Political Change Under A Radical Left Government: The Case of Barcelona." Journal of Urban Affairs 42 (1): 18-38. https://doi.org/10.1080/07352166. 2018.1559648.

Boddy, Martin, and Colin Fudge. 1984. Local Socialism. London: MacMillan.

Boudreau, Julie-Anne. 2017. Global Urban Politics. Cambridge, UK: Polity Press.

Burwood, Stephen. 2003. "Debsian Socialism Through A Transnational Lens." The Journal of the Gilded Age and Progressive Era 2 (3): 253-82. https://doi.org/ $10.1017 / \mathrm{S} 1537781400000414$.

Clancey, Gregory. 2004. "Local Memory and Worldly Narrative: The Remote City in America and Japan ." Urban Studies 41 (12): 2335-55.

Clarke, Nick, and Allan Cochrane. 2013. "Geographies and Politics of Localism: The Localism of the United Kingdom's Coalition Government." Political Geography 34: 10-23. https://doi.org/10.1016/j.polgeo.2013.03.003.

Clavel, Pierre. 1986. The Progressive City: Planning and Participation, 1969-1984. Brunswick: Rutgers University Press.

Clavel, Pierre. 2010. Activists in City Hall: The Progressive Response to the Reagan Era in Boston and Chicago. Ithaca: Cornell University Press.

Cochrane, Allan. 1998. "Illusions of Power: Interviewing Local Elites." Environment and Planning A: Economy and Space 30 (12): 2121-32. https://doi.org/10.1068\% $2 \mathrm{Fa} 302121$.

Cochrane, Allan. 2016. "Thinking About the 'Local' of Local Government: A Brief History of Invention and Reinvention.” Local Government Studies 42 (6): 907-15. https://doi.org/10.1080/03003930.2016.1228530.

Connolly, Kate. 2019. "Far-right AfD Bids to Encircle Berlin as Resentment and Division Grow." The Guardian, September 1. https://www.theguardian.com/ world/2019/sep/01/afd-bids-to-encirle-berlin-saxony-brandenburg-state-elections Cooper, Davina. 2016. "Transformative State Publics." New Political Science 38 (3): 315-34. https://doi.org/10.1080/07393148.2016.1189028. 
Cruddas, Jon. 2019. “The Left's New Urbanism.” The Political Quarterly 90 (1): 15-22. https://doi.org/10.1111/1467-923X.12639.

Dau, Elisabeth. 2020. Against the Tide: A Review of the 2020 French Municipal Elections and the Dynamics of Participatory Lists. MINIM Report 2. https:// minim-municipalism.org/wp-content/uploads/2020/11/Against-the-Tide.pdf

Davies, Jonathan. 2021. Between Realism and Revolt. Governing Cities in the Crisis of Neoliberal Globalism. Bristol: Bristol University Press.

Della Porta, Donatella. 2020. How Social Movements Can Save Democracy. Cambridge, UK: Polity Press.

DIE LINKE Landesverband Brandenburg. 2021. DIE LINKE. Brandenburg. https:// www.dielinke-brandenburg.de/partei/strukturen/

Douglass, Mike, Romaine Garbaye, and Kong Chong Ho. 2019. The Rise of Progressive Cities East and West. Singapore: Springer.

Featherstone, David, Anthony Ince, Danny Mackinnon, Kendra Strauss, and Andrew Cumbers. 2012. "Progressive Localism and the Construction of Political Alternatives." Transactions of the Institute of British Geographers 37 (2): 177-82. https://doi.org/10.1111/j.1475-5661.2011.00493.x.

Featherstone, David, Jo Littler, and Sallie Davison. 2020. "Re-Empowering the Local: New Municipal Alternatives." Soundings: A Journal of Politics and Culture 74: 4-9.

Förtner, Maximilian, Bernd Belina, and Matthias Naumann. 2021. "The Revenge of the Village? The Geography of Right-Wing Populist Electoral Success, Anti-Politics, and Austerity in Germany." Environment and Planning C: Politics and Space 39 (3): 574-96. https://doi.org/10.1177\%2F23996544209 51803.

Fröschner, Joschka, and Jakob Warnecke. 2019. Was interessiert mich denn Cottbus? Dynamiken rechter Formierung in Südbrandenburg: Der Verein Zukunft Heimat. Berlin and Potsdam: Rosa-Luxemburg-Stiftung and Aktionsbündnis gegen Gewalt, Rechtsextremismus und Fremdenfeindlichkeit.

Fuller, Crispian. 2018. "Entrepreneurial Urbanism, Austerity and Economic Governance." Cambridge Journal of Regions, Economy and Society 11 (3): 565-85. https://doi.org/ 10.1093/cjres/rsy023.

Gillespie, Tom, Kate Hardy, and Paul Watt. 2021. "Surplus to the City: Austerity Urbanism, Displacement and 'Letting Die'." Environment and Planning A: Economy and Space 53 (7): 1713-29. https://doi.org/10.1177\%2F0308518X2 11026323.

Hamann, Ulrike, and Ceren Türkmen. 2020. "Communities of Struggle: The Making of A Protest Movement Around Housing, Migration and Racism Beyond Identity Politics in Berlin.” Territory, Politics, Governance 8 (4): 515-31. https://doi.org/ 10.1080/21622671.2020.1719191.

Harvey, David. 2012. Rebel Cities. London and New York: Verso.

Holm, Andrej. 2021. "From Protest to Program Berlin's Anti-Gentrification-Movement Since Reunification." In Social Movements and Public Policies in Southern European Cities. Urban and Landscape Perspectives, edited by Laura Fregolent, and Oriol Nel·lo, 33-52. New York: Springer. 
Holm, Andrej, Klaus Lederer, and Matthias Naumann. 2011. Linke Metropolenpolitik. Bilanz und Perspektiven am Beispiel Berlin. Münster: Westfälisches Dampfboot. Iammarino, Simona, Andrés Rodriguez-Pose, and Michael Storper. 2018. "Regional Inequality in Europe: Evidence, Theory and Policy Implications." Journal of Economic Geography 19 (2): 273-98. https://doi.org/10.1093/jeg/lby021.

Imbroscio, David. 2019. "The Perils of Rationalism in American Urban Policy." Urban Affairs Review 45 (1): 74-107. https://doi.org/10.1177\%2F107808741 7690834.

Janoschka, Michael, and Fabiola Mota. 2020. "New Municipalism in Action or Urban Neoliberalisation Reloaded? An Analysis of Governance Change, Stability and Path Dependence in Madrid (2015-2019)." Urban Studies 58 (13): 2814-30. https://doi.org/10.1177\%2F0042098020925345.

Joy, Meghan, and Ronald Vogel. 2021. "Beyond Neoliberalism: A Policy Agenda for A Progressive City." Urban Affairs Review 57 (5): 1372-409. https://doi.org/10. 1177\%2F1078087420984241.

Keil, Roger. 2017. Suburban Planet: Making the World Urban From the Outside In. Cambridge, UK: Polity Press.

Knotter, Ad. 2011. "'Little Moscows' in Western Europe: The Ecology of Small-Place Communism." International Review of Social History 56 (3): 475-510. https:// doi:10.1017/S0020859011000381.

Kohn, Margaret. 2003. Radical Space: Building the House of the People. Ithaca: Cornell University Press.

Landesamt für Bauen und Verkehr. 2020. Monitoring von raumstrukturellen Entwicklungstrends in der Hauptstadtregion 2019/2020. https://lbv.brandenburg.de/ dateien/stadt_wohnen/Raumentwicklungstrends_2020_Kapitel_1_Bevoelkerung Text.pdf

Landeswahlleiter Brandenburg. 2020. Überblick über sämtliche Wahlergebnisse im Land Brandenburg. https://wahlen.brandenburg.de/sixcms/media.php/9/Wahlergebnisse_ seit_1990_alle_Wahlen.3891774.pdf

Lefebvre, Henri. 2003. The Urban Revolution. Minneapolis: University of Minnesota Press.

Leopold, Ellen, and David McDonald. 2012. "Municipal Socialism Then and Now: Some Lessons for the Global South." Third World Quarterly 33 (10): 1837-53. https://doi.org/10.1080/01436597.2012.728321.

Magnusson, Warren. 2015. Local Self-Government and the Right to the City. Montreal: McGill-Queen's University Press.

Mayer, Margit. 2013. "First World Urban Activism." City 17 (1): 5-19. https://doi.org/ 10.1080/13604813.2013.757417.

Mayer, Margit. 2016. "Re-Thinking Urban Social Movements, 'Riots' and Uprisings: An Introduction." In Urban Uprisings. Challenging Neoliberal Urbanism in Europe, edited by Margit Mayer, Catharina Thörn, and Hakan Thörn, 3-55. Basingstoke: Palgrave Macmillan.

Mayer, Margit. 2018. "Cities as Sites of Refuge and Resistance." European Urban and Regional Studies 25 (3): 232-49. https://doi.org/10.1177\%2F096977641 7729963. 
Mayer, Margit, and Julie-Anne Boudreau. 2012. "Social Movements in Urban Politics: Trends in Research and Practice." In The Oxford Handbook of Urban Politics, edited by Peter John, Karen Mossberger, and Susan E. Clarke, 273-91. Oxford: Oxford University Press.

Mayring, Philipp. 2004. "Qualitative Content Analysis.” In A Companion to Qualitative Research, edited by Uwe Flick, Ernst von Kardoff, and Ines Steinke, 159-76. Thousand Oaks: Sage.

Milburn, Keir, and Bertie Russell. 2018. "What Can an Institution Do? Towards Public-Common Partnerships and a New Common-sense." Renewal: A Journal of Social Democracy 26 (4): 45-55.

Miliband, Ralph. 2009. Parliamentary Socialism: A Study in the Politics of Labour. London: Merlin Press.

Nicholls, Walter, and Justus Uitermark. 2017. Cities and Social Movements: Immigrant Rights Activism in the United States, France, and the Netherlands, 1970-2015. London: Wiley.

Peck, Jamie. 2012. “Austerity Urbanism.” City 16 (6): 626-55. https://doi.org/10. 1080/13604813.2012.734071.

People's Action. n.d. https://peoplesaction.org/ (accessed 20 September 2021).

Petzold, Tino. 2018. Austerity Forever?! Die Normalisierung der Austerität in der $B R D$. Münster: Westfälisches Dampfboot.

Purcell, Mark. 2006. "Urban Democracy and the Local Trap." Urban Studies 43 (11): 1921-41. https://doi.org/10.1080\%2F00420980600897826.

Rodríguez-Pose, Andrés. 2017. "The Revenge of the Places That Don't Matter (And What to do About It)." Cambridge Journal of Regions, Economy and Society 11 (1): 189-209. https://doi.org/10.1093/cjres/rsx024.

Rossi, Ugo. 2018. "The Populist Eruption and the Urban Question." Urban Geography 39 (9): 1425-30. https://doi.org/10.1080/02723638.2018.1448135.

Russell, Bertie. 2019. "Beyond the Local Trap: New Municipalism and the Rise of Fearless Cities." Antipode 51 (3): 989-1010. https://doi.org/10.1111/anti.12520.

Self, Robert. 2003. American Babylon: Race and the Struggle for Postwar Oakland. Princeton: Princeton University Press.

Skinner, Mark, Alun Joseph, and Rachel Herron. 2016. "Voluntarism, Defensive Localism and Spaces of Resistance to Health Care Restructuring." Geoforum; Journal of Physical, Human, and Regional Geosciences 72: 67-75. https://doi. org/10.1016/j.geoforum.2016.04.004.

Statistische Ämter des Bundes und der Länder. 2020. Bevölkerung in Brandenburg. http://www.statistikportal.de/de/brandenburg/bevoelkerung

Stone, Clarence. 1989. Regime Politics: Governing Atlanta, 1946-1988. Lawrence: University of Kansas Press.

Theodore, Nik. 2020. "Governing Through Austerity: (Il)Logics of Neoliberal Urbanism After the Global Financial Crisis." Journal of Urban Affairs 42 (1): 1-17. https://doi.org/10.1080/07352166.2019.1623683.

Thompson, Matthew. 2021. "What's so New About New Municipalism?" Progress in Human Geography 45 (2): 317-42. https://doi.org/10.1177\%2F03091325209 09480 . 
Tonkiss, Fran. 2020. "City Government and Urban Inequalities." City 24 (1-2): 286-301. https://doi.org/10.1080/13604813.2020.1739931.

Wills, Jane. 2016. Locating Localism: Statecraft, Citizenship and Democracy. Cambridge, UK: Policy Press.

Wolf, Harald. 2016. Rot-Rot in Berlin. 2002 bis 2011: eine (selbst-)kritische Bilanz. Hamburg: VSA.

Wolin, Sheldon. 2016. Fugitive Democracy: And Other Essays. Princeton: Princeton University Press.

\section{Author Biographies}

Ross Beveridge is an Urban Studies Foundation Senior Research Fellow in the School of Social and Political Sciences at the University of Glasgow and a Research Fellow at the Department of Regional Planning at the Brandenburg University of Technology, Cottbus-Senftenberg. His research interests lie in the fields of urban and regional politics.

Matthias Naumann is a Professor of Geography and Regional Studies at the University of Klagenfurt (Austria). Naumann's research interests include urban and rural development, the transformation of infrastructure, and political geography. $\mathrm{He}$ has held several research and teaching positions in the Berlin-Brandenburg region. 